\title{
Association of GH Gene Polymorphism with Semen Parameters of Boars
}

\author{
M. KMIEĆ ${ }^{1}$, A. TERMAN ${ }^{1}$, H. WIERZBICKI ${ }^{2}$, S. ZYCH ${ }^{1}$ \\ ${ }^{1}$ Agricultural University of Szczecin, Department of Genetics and Animal Breeding, Szczecin, Poland, \\ ${ }^{2}$ Agricultural University of Wroclaw, Department of Genetics and Animal Breeding, Wroclaw, Poland \\ Received November 25, 2005 \\ Accepted September 5, 2006
}

\begin{abstract}
Kmieć M., A. Terman, H. Wierzbicki, S. Zych: Association of GH Gene Polymorphism with Semen Parameters of Boars. Acta Vet 2007, 76: 41-46.

Relations between polymorphism of the Growth Hormone gene and semen characters were analyzed. The DNA for the purpose of examination was isolated from the peripheral blood of 173 boars. In the boar herd under study the frequency of allele occurrence for the $\mathrm{GH} / \mathrm{MspI}$ was as follows: allele $G H^{\mathrm{A}}-0.79$ and allele $G H^{\mathrm{B}}-0.21$. As far as the GH/HaeII polymorphism is concerned, the relevant frequency was as follows: allele $G H^{\mathrm{A}}-0.53$ and allele $G H^{\mathrm{B}}-0.47$, respectively. The relationship between the $G H$ genotypes and semen characteristic traits were analyzed. The study showed that boars with $G H^{\mathrm{B}} G H^{\mathrm{B}}$ genotype of both polymorphous loci of the $\mathrm{GH}$ gene produced ejaculates of larger volume, higher percentage, number of normozosperms in the ejaculate and number of insemination as compared to $G H^{\AA} G H^{\mathrm{A}}$ and $G H^{\mathrm{A}} G H^{\mathrm{B}}$ boars. Our current findings suggested that polymorphism of the GH/MspI and GH/HaeII might have potential effect for reproductive performance traits of boars.
\end{abstract}

GH gene, polymorphism, PCR-RFLP, boars, semen characteristics

Growth hormone is a protein produced in the anterior pituitary and its secretion varies throughout the entire life of an animal - it peaks in puberty and then remains slightly lower (Machnik and Lechniak 2000) and depends on sex and physiological condition (Izadyar et al. 1999), e.g. in cows during lactation it is close to zero. The hormone concerned affects target cells in direct or indirect manner. Results of the study showed that the $G H$ directly affects the steroidogenesis, gametogenesis and gonad differentiation (Zachman 1992; Franks 1998). Reportedly it also plays a major role in the growth and development of testis since the discovery of the relation between the $G H$ deficiency and male hypogonadism in humans (Spiteri-Grech and Nieschlag 1992).

It has been proved that the $G H$ and IGF-I under in vitro conditions influence the growth and division rate of the sustentacular (Sertoli) cells and interstitial (Leydig) cells and the IGF-II stimulates the differentiation of Sertoli cells. The testis performance and steroidogenesis and gametogenesis could simultaneously be affected by testicular and hypophyseal growth hormones (Hull and Harvey 2000). Clinical examinations in men showed that the $G H$ is required to maintain the correct sperm morphology and sperm concentration (Gravance et al. 1997). In case of the hormone deficiency, the sperm movement in men was limited and restored only after the administration of exogenous $G H$ (Gravance et al. 1997; Breier et al. 1998). Somatotropin also affects the prostate indirectly through the regulation of somatomedine $\mathrm{C}$ concentration and a number of receptors (Reiter et al. 1999); it may also be an essential hormone during the period of penis development (Laron and Klinger 1998).

The $G H$ gene in pigs is located on the chromosome 12 (Yerle et al. 1993) and consists of 5 exons, the total length of which is $1.7 \mathrm{~kb}$ ( Vize and Wells 1987).

The genetic polymorphism of the $G H$ gene in pigs was found and about 20 genetic variations of the $G H$ gene in different breeds and lines of pigs were described

\footnotetext{
Address for correspondence:

Prof. Dr. Marek Kmieć

Department of Genetics and Animal Breeding

ul. Doktora Judyma 6,

71-466 Szczecin, Poland
}

Phone/fax: +48914541497

E-mail: m.kmiec@biot.ar.szczecin.pl

http://www.vfu.cz/acta-vet/actavet.htm 
(Schellander et al. 1994; Handler et al. 1995; Knorr et al. 1997). Relations between certain genetic variations of the $G H$ gene in pigs and carcass fat deposition and meat quality (Gelderman et al. 1996) and the loin eye area and fat deposition were identified to show that the $G H$ gene is a gene-candidate for the fat deposition in pigs (Knorr et al. 1997).

Taking into account numerous reports on potential reproduction functions of the $G H$ and relations between the $G H$ genetic variations and meat performance in livestock, this study was aimed at the detection of the mutation in the $G H$ gene and identification of the genetic structure of the insemination boar herd and establishment of relations between the $G H$ genetic variations and qualitative and quantitative traits of the insemination boar semen.

\section{Materials and Methods}

The study included 173 breeding boars kept at the AI station that served to inseminate sows in the station operation area (Table 1). All the boars were kept in the same conditions and used for insemination purposes only.

Table 1. The number and frequency of GH1/MspI genotype and alleles of boars under study

\begin{tabular}{|l|c|c|c|c|c|c|}
\hline \multirow{2}{*}{ Breed } & \multirow{2}{*}{$\mathrm{N}$} & \multicolumn{3}{|c|}{$G H$ genotype } & \multicolumn{2}{c|}{$G H$ allele } \\
\cline { 3 - 7 } & & $A A$ & $A B$ & $B B$ & \multicolumn{2}{c|}{ A } \\
\hline Polish Landrace & 52 & 0.92 & 0.08 & - & 0.96 & 0.04 \\
\hline Duroc $\times$ Pietrain & 43 & 0.49 & 0.46 & 0.05 & 0.72 & 0.28 \\
\hline Polish Large White & 35 & 0.51 & 0.46 & 0.03 & 0.74 & 0.26 \\
\hline Hampshire $\times$ Pietrain & 25 & 0.32 & 0.60 & 0.08 & 0.62 & 0.38 \\
\hline PIC synthetic line & 18 & 0.61 & 0.39 & - & 0.81 & 0.19 \\
\hline Total & 173 & 0.61 & 0.36 & 0.03 & 0.79 & 0.21 \\
\hline
\end{tabular}

The data were collected on 19,379 ejaculates sampled from 173 boars between 1996 and 2002 and referred to ejaculate volume, sperm concentration, live sperm percentage, number of live sperm in ejaculate, number of insemination doses. In order to eliminate the age effect, only the data on 4,713 ejaculates sampled from boars at the age of 221 to 240 days were analyzed. The semen sampling period was divided into 12 months, and along with the year, breed and father's effect were taken into consideration when defining the variation.

The DNA for the examination was isolated from peripheral blood with Master Pure ${ }^{\mathrm{TM}}$ Genomic DNA Purification Kit of Epicenter Technologies. Such isolation procedure produced the DNA of $75-85 \mu \mathrm{g} / \mathrm{ml}$ concentration and over $85 \%$ purity.

The PCR-RFLP method was applied to determine the $G H$ genotypes. The PCR reaction was conducted in $20 \mu \mathrm{l}$ mixture of the following thermal profile: 1) $\left.\left.\left.94{ }^{\circ} \mathrm{C} / 5 \mathrm{~min}, 2\right) 94{ }^{\circ} \mathrm{C} / 45 \mathrm{sec}, 3\right) 57{ }^{\circ} \mathrm{C} / 45 \mathrm{sec}, 4\right) 72{ }^{\circ} \mathrm{C} / 45 \mathrm{sec}, 5$ ) $72^{\circ} \mathrm{C} / 5 \mathrm{~min}$.; the reaction covered 35 cycles (stages 2 through 4 ). Starter sequences were used (forward primer: $5^{\prime}-$ GCC AAG TTT TAA ATG TCC CTG-3' and reverse primer: 5'-CTG TCC CTC CGG GAT GTA G-3') for the PCR reaction to identify the DNA fragment of $506 \mathrm{bp}$. The said amplified fragment of $506 \mathrm{bp}$ was digested for 3 hours at $37^{\circ} \mathrm{C}$ with 4 I.U. of restriction enzyme MspI or 4 I.U. of restriction enzyme HaeII, respectively. The restrictive fragments of the DNA were separated by means of the electrophoresis in $2 \%$ agarose gel stained with ethidium bromide in the $1 \times \mathrm{TBE}$ buffer. Then, the gels were visualized and analyzed in the UV rays and recorded with the use of the Vilber Lourmat system.

The statistical analysis of relations was carried out by means of the SAS/STAT (General Linear Model Procedure) calculation package according to the following linear model:

$Y_{i j k l}=m+G_{i}+B_{j}+Y_{k}+S_{1}+e_{i j k l}$

where:

$\mathrm{Y}_{\mathrm{ijklm}}$ - character value for i-th genotype, $\mathrm{j}$-th boar breed, $\mathrm{k}$-th year season, 1-th sire;

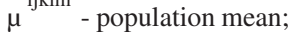

$\mathrm{G}_{\mathrm{i}} \quad$ - effect of $\mathrm{i}$-th genotype $(\mathrm{i}=1,2,3)$;

$\mathrm{B}_{\mathrm{j}} \quad$ - constant effect of $\mathrm{j}$-th boar breed $(\mathrm{j}=1,2, \ldots, 5)$;

$\mathrm{YS}_{\mathrm{k}}$ - constant effect of $\mathrm{k}$-th year season $(\mathrm{k}=1,2, \ldots, 28)$ - (7 years $* 4$ seasons);

$\mathrm{S}_{1} \quad$ - fixed effect of the 1-th sire $(1=1,2, \ldots, 94)$;

$\mathrm{e}_{\mathrm{ijklm}}$ - random residual term. 
Results presented in Tables 3 and 4 show the number and characteristics of semen samples and mean values and standard deviations.

\section{Results}

Due to the application of starter sequences a product of $506 \mathrm{bp}$ size that covered the range from $+385^{\text {th }}$ base of intron I to $+889^{\text {th }}$ base of intron III of the certain $G H$ gene of livestock was amplified. After the digestion with endonuclease $M s p \mathrm{I}$, that identified sequences 5'CZCGG-3' and 3'-GGC-C-5' in the second intron of $G H$ gene various arrays of bands were found in the agarose gel and thus two alleles $G H^{\mathrm{A}}$ and $G H^{\mathrm{B}}$ were found that affect the occurrence of three genotypes $\left(G H^{\mathrm{A}} G H^{\mathrm{A}}-222,147\right.$ and $137 \mathrm{bp} ; G H^{\mathrm{A}} G H^{\mathrm{B}}-284,222,147$ and $137 \mathrm{bp}$ and $G H^{\mathrm{B}} G H^{\mathrm{B}}-284$ and 222 bp compared to DNA pUC19/MspI molecular marker). Table 1 lists frequencies of identified GH/MspI genotypes and alleles in the boar herd under study. The frequency of $G H^{\mathrm{A}}$ allele was 0.79 and that of $G H^{\mathrm{B}}$ allele was 0.21 . The frequency of the $G H^{\mathrm{A}} G H^{\mathrm{A}}$ genotype in the boar herd under study was 0.61 . The highest frequency was found in Polish Landrace boars $(0.92)$, and the lowest in Hampshire $\times$ Pietrain boars $(0.32)$. The frequency of the $G H^{\mathrm{A}} G H^{\mathrm{B}}$ genotype was 0.36 . In the boars herd under study the highest frequency of this genotype was found in Hampshire $\times$ Pietrain cross-breed boars $(0.60)$. The frequency of the $G H^{\mathrm{B}} G H^{\mathrm{B}}$ genotype in the insemination boars herd under study was 0.03 . The highest value was found in Hampshire $\times$ Pietrain boars $(0.08)$, whereas in Polish Landrace and PIC boars did not exhibit the genotype concerned (Table 1) .

The amplified product of $506 \mathrm{bp}$ was subject to the digestion with endonuclease HaeII, that identified sequences 5'-RGCGCZY $\downarrow$ 3' and 3'-Y $\uparrow$ CGCGR-5' (where R = G or A, Y = $\mathrm{C}$ or $\mathrm{T}$ ) in the second exon of $\mathrm{GH}$ gene and various arrays of strips were found in the agarose gel and thus two alleles $G H^{\mathrm{A}}$ and $G H^{\mathrm{B}}$ were found that affect the occurrence of three genotypes $\left(G H^{\mathrm{A}} G H^{\mathrm{A}}-337\right.$ and $173 ; G H^{\mathrm{A}} G H^{\mathrm{B}}-506,333$ and 173 bp and $G H^{\mathrm{B}} G H^{\mathrm{B}}-506$ bp compared to DNA pUC19/MspI molecular marker).

Table 2. The number and frequency of GH1/HaeII genotype and alleles of boars under study

\begin{tabular}{|l|c|c|c|c|c|c|}
\hline \multirow{2}{*}{ Breed } & \multirow{2}{*}{$\mathrm{N}$} & \multicolumn{3}{|c|}{$G H$ genotype } & \multicolumn{2}{c|}{$G H$ allele } \\
\cline { 3 - 7 } & & $A A$ & $A B$ & $B B$ & \multicolumn{2}{c|}{$A$} \\
\hline Polish Landrace & 52 & 0.06 & 0.48 & 0.46 & 0.30 & 0.70 \\
\hline Duroc $\times$ Pietrain & 43 & 0.49 & 0.39 & 0.12 & 0.69 & 0.31 \\
\hline Polish Large White & 35 & 0.37 & 0.57 & 0.06 & 0.66 & 0.34 \\
\hline Hampshire $\times$ Pietrain & 25 & 0.24 & 0.64 & 0.12 & 0.56 & 0.44 \\
\hline PIC synthetic line & 18 & 0.22 & 0.56 & 0.22 & 0.50 & 0.50 \\
\hline Total & 173 & 0.27 & 0.51 & 0.22 & 0.53 & 0.47 \\
\hline
\end{tabular}

Table 2 lists frequencies of identified GH/HaeII genotypes and alleles in the boar herd under study. The frequency of $G H^{\mathrm{A}}$ allele was 0.53 and that of $G H^{\mathrm{B}}$ allele was 0.47 . The frequency of the $G H^{\mathrm{A}} G H^{\mathrm{A}}$ genotype in the boar herd under study was 0.27 and varied among breeds, from 0.06 in the Polish Landrace to 0.49 in Duroc $\times$ Pietrain pigs (Table 2). The frequency of the $G H^{\mathrm{A}} G H^{\mathrm{B}}$ genotype was 0.51 and the values ranged from 0.39 to 0.64 . The lowest frequency in the insemination boar herd under study was reported for the $G H^{\mathrm{B}} G H^{\mathrm{B}}$ - 0.22 (Table 2).

The analysis of relations between $G H / M s p$ I polymorphism showed that ejaculates of highest volume were produced by the boars of the $G H^{\mathrm{B}} G H^{\mathrm{B}}\left(244.6 \mathrm{~cm}^{3}\right)$ whereas the boars of $G H^{\mathrm{A}} G H^{\mathrm{A}}$ and $G H^{\mathrm{A}} G H^{\mathrm{B}}$ genotypes produced smaller ejaculates: $215.5 \mathrm{~cm}^{3}$ and 212.0 $\mathrm{cm}^{3}$, respectively (Table 3 ). The study showed significantly higher sperm concentration in boars of the $G H^{\mathrm{A}} G H^{\mathrm{A}}$ and $G H^{\mathrm{A}} G H^{\mathrm{B}}$ genotypes rather than the $G H^{\mathrm{B}} G H^{\mathrm{B}}$, and the difference in the sperm concentration between the boars of the $G H^{\mathrm{A}} G H^{\mathrm{A}}$ and $G H^{\mathrm{A}} G H^{\mathrm{B}}$ were small and 
Table 3. Values of studied semen traits in reference to GH/MspI genotype

\begin{tabular}{|l|c|c|c|c|c|}
\hline \multirow{2}{*}{ Character } & \multicolumn{3}{|c|}{$G H / M s p$ I genotype } & \multirow{2}{*}{ Total } \\
\cline { 3 - 6 } & & $G H^{A} G H^{A}$ & $G H^{A} G H^{B}$ & $G H^{B} G H^{B}$ & \\
\hline \multirow{2}{*}{ Ejaculate volume $\left[\mathrm{cm}^{3}\right]$} & Mean & $215.5^{\mathrm{A}}$ & $212.0^{\mathrm{B}}$ & $244,6^{\mathrm{AB}}$ & 216.4 \\
& $\pm \mathrm{SD}$ & 73.9 & 79.3 & 102.6 & 78.8 \\
\hline Sperm concentration & Mean & $603.4^{\mathrm{A}}$ & $600.5^{\mathrm{B}}$ & $569.1^{\mathrm{AB}}$ & 599.7 \\
{$\left[\times \cdot 10^{6} / \mathrm{cm}^{3}\right]$} & $\pm \mathrm{SD}$ & 123.7 & 125.1 & 110.7 & 123.5 \\
\hline \multirow{2}{*}{ Live sperm percentage } & Mean & $72.5^{\mathrm{A}}$ & $72.5^{\mathrm{B}}$ & $73.5^{\mathrm{AB}}$ & 72.6 \\
& $\pm \mathrm{SD}$ & 4.7 & 4.9 & 5.2 & 4.8 \\
\hline Number of alive sperms & Mean & $90.9^{\mathrm{AB}}$ & $87.6^{\mathrm{AC}}$ & $92.4^{\mathrm{BC}}$ & 89.8 \\
in ejaculate $\left[\times \cdot 10^{9}\right]$ & $\pm \mathrm{SD}$ & 32.4 & 31.7 & 39.0 & 32.7 \\
\hline \multirow{2}{*}{ Number of insemination doses } & Mean & 24.3 & 23.3 & 23.7 & 23.9 \\
& $\pm \mathrm{SD}$ & 8.8 & 8.3 & 10.3 & 8.8 \\
\hline
\end{tabular}

Mean values in a line designated with the same letter differ significantly at $P \leq 0.01$

statistically non-significant (Table 3). The relations between GH/MspI polymorphism and the average percentage of live sperms in the boar semen show that the percentage of live sperms in the semen of the $G H^{\mathrm{B}} G H^{\mathrm{B}}$ genotype boars was significantly higher than in the semen of the $G H^{\mathrm{A}} G H^{\mathrm{B}}$ and $G H^{\mathrm{A}} G H^{\mathrm{A}}$ boars, and the differences were confirmed statistically (Table 3). It was also shown that the semen from the $G H^{\mathrm{B}} G H^{\mathrm{B}}$ genotype boars contained a greater number of live sperms than ejaculates from the boars of the $G H^{\mathrm{A}} G H^{\mathrm{B}}$ and $G H^{\mathrm{A}} G H^{\mathrm{A}}$ genotypes. Ejaculates yielded from the $G H^{\mathrm{A}} G H^{\mathrm{B}}$ genotype boars exhibited the smallest number of live sperms per ejaculate and the differences were confirmed statistically (Table 3). One ejaculate from the boar in the herd under study produced 23.9 insemination doses. The greatest number of insemination doses was produced from ejaculates of the $G H^{\mathrm{A}} G H^{\mathrm{A}}$ genotype boars, and the smallest of the $G H^{\mathrm{A}} G H^{\mathrm{B}}$ boars, the differences, however, were minor and not confirmed statistically (Table 3 ).

Table 4. Values of studied semen traits in reference to GH/HaeII genotype

\begin{tabular}{|l|c|c|c|c|c|}
\hline \multirow{2}{*}{ Character } & \multicolumn{3}{|c|}{ GH/HaeII genotype } & \multirow{2}{*}{ Total } \\
\cline { 3 - 6 } & & $G H^{A} G H^{A}$ & $G H^{A} G H^{B}$ & $G H^{B} G H^{B}$ & \\
\hline \multirow{2}{*}{ Ejaculate volume $\left[\mathrm{cm}^{3}\right]$} & Mean & $209.7^{\mathrm{A}}$ & $207.9^{\mathrm{B}}$ & $229.2^{\mathrm{AB}}$ & 216.4 \\
& $\pm \mathrm{SD}$ & 78.3 & 72.6 & 78.9 & 78.8 \\
\hline Sperm concentration & Mean & $601.2^{\mathrm{A}}$ & $610.0^{\mathrm{B}}$ & $586.4^{\mathrm{AB}}$ & 599.7 \\
{$\left[\times \cdot 10^{6} / \mathrm{cm}^{3}\right]$} & $\pm \mathrm{SD}$ & 122.5 & 122.3 & 126.8 & 123.5 \\
\hline \multirow{2}{*}{ Live sperm percentage } & Mean & $72.4^{\mathrm{A}}$ & $72.2^{\mathrm{B}}$ & $73.1^{\mathrm{AB}}$ & 72.6 \\
& $\pm \mathrm{SD}$ & 4.9 & 4.4 & 4.9 & 4.8 \\
\hline Number of alive sperms & Mean & $89.1^{\mathrm{A}}$ & $89.0^{\mathrm{B}}$ & $95.2^{\mathrm{AB}}$ & 89.8 \\
in ejaculate $\left[\times \cdot 10^{9}\right]$ & $\pm \mathrm{SD}$ & 34.8 & 29.3 & 28.4 & 32.7 \\
\hline \multirow{2}{*}{ Number of insemination doses } & Mean & $23.4^{\mathrm{A}}$ & $23.4^{\mathrm{B}}$ & $25.6^{\mathrm{AB}}$ & 23.9 \\
& $\pm \mathrm{SD}$ & 9.3 & 8.2 & 8.0 & 8.8 \\
\hline
\end{tabular}

Mean values in a line designated with the same letter differ significantly at $P \leq 0.01$

Table 4 lists average parameters of semen characters of insemination boars versus $G H / H a e$ II polymorphism. It was shown that the $G H^{\mathrm{B}} G H^{\mathrm{B}}$ genotype boars produced ejaculates of significantly greater volume than the boars of other GH/HaeII genotypes. The analysis of relations between $\mathrm{GH} / \mathrm{Hae}$ II genotypes and sperm concentration showed the smallest value in boars with $G H^{\mathrm{B}} G H^{\mathrm{B}}$ genotype and the differences were statistically confirmed. The highest percentage of live sperms and the greatest number of live sperms per 
ejaculate were found in ejaculates produced by the $G H^{\mathrm{B}} G H^{\mathrm{B}}$ boars and the differences were statistically confirmed (Table 4). Ejaculates taken from the $G H^{\mathrm{A}} G H^{\mathrm{A}}$ and $G H^{\mathrm{A}} G H^{\mathrm{B}}$ boars produced 23.4 insemination doses on average, whereas ejaculates taken from the $G H^{\mathrm{B}} G H^{\mathrm{B}}$ boars produced 25.6 doses on average, respectively. The ejaculates taken from the $G H^{\mathrm{B}} G H^{\mathrm{B}}$ genotype boars produced by 2.2 insemination doses more than the ones from the $G H^{\mathrm{A}} G H^{\mathrm{A}}$ and $G H^{\mathrm{A}} G H^{\mathrm{B}}$ boars and the difference was confirmed statistically (Table 4).

\section{Discussion}

The higher frequency of the $G H^{\mathrm{A}} G H^{\mathrm{A}}(G H / M s p \mathrm{I})$ was reported by Schellander et al. (1994) - 0.96 and Handler et al. (1995) - 0.86. The extremely low frequency of this genotype, however, was reported by Kuciel et al. (1998) - 0.27. The higher frequency of the $G H^{\mathrm{A}} G H^{\mathrm{B}}$ genotype concerned was found by Kuciel et al. (1998) - 0.58, whereas Handler et al. (1995) reported a much lower value of 0.12 . The frequency of the $G H^{\mathrm{B}} G H^{\mathrm{B}}$ genotype in herds of pigs researched by Handler et al. (1995) and Schellander et al. (1994) was low and amounted to: 0.02 and 0.01, respectively. Only Kuciel et al. (1998) reported the higher frequency of the genotype concerned, i.e. 0.15.

The same frequency of the above alleles of GH/HaeII was reported by Kuciel et al. (1998), and very similar values were reported by Puntova et al. (2001). High frequency of the $G H^{\mathrm{A}}$ was reported by Kirkpatrick (1993) - 0.82 whereas the analysis of the polymorphism by Handler et al. (1995) and Schellander et al. (1994) showed much lower values of the allele concerned, i.e. 0.24 and 0.17 , respectively. Similar values of the $G H^{\mathrm{A}} G H^{\mathrm{A}}$ were reported by Kuciel et al. (1998) - 0.26, whereas much lower values were given by Handler et al. (1995) - 0.10 and Schellander et al. (1994) - 0.05. Kuciel et al. (1998) reported similar values of the $G H^{\mathrm{A}} G H^{\mathrm{B}}$ genotype $(0.58)$ whereas lower ones were given by Schellander et al. (1994) - 0.24 and Handler et al. (1995) - 0.28. Similar frequency of the $G H^{\mathrm{B}} G H^{\mathrm{B}}$ genotype in pigs was reported by Kuciel et al. (1998) - 0.16. High frequency in the boar herd was reported by Handler et al. (1995) - 0.62 and Schellander et al. (1994) - 0.71.

The analysis of ejaculate volume showed that the average of this trait in the boar herd was $21.6,4 \mathrm{~cm}^{3}$ and by far exceeded the values given by Wierzbowski (1996) $-200 \mathrm{~cm}^{3}$. The sperm concentration in the boar herd under study was $599.7 \mathrm{mln} / \mathrm{cm}^{3}$ and exceeded the average value given by Wierzbowski (1996). The study showed also similar number of insemination doses per ejaculate as reported by Kondracki et al. (1998).

Our study showed that boars with $G H^{\mathrm{B}} G H^{\mathrm{B}}$ genotype of both polymorphous loci of the $G H$ gene ( $p G H / M s p$ I and $p G H / H a e I I)$ produced ejaculates of larger volume, higher percentage, number of normozosperms in the ejaculate and number of insemination does compared to $G H^{\mathrm{A}} G H^{\mathrm{A}}$ and $G H^{\mathrm{A}} G H^{\mathrm{B}}$ boars. Statistically significant $(P \leq 0.01)$ differences were found between $p G H / M s p$ I and $p G H / H a e I I$ genotypes and qualitative and quantitative semen characters under study.

The study confirmed the occurrence of $p G H / M s p I$ and $p G H / H a e I I$ polymorphism in a selected sequence of the $G H$ gene and the results of the analysis of relations suggest possibilities to use existing polymorphism in the $G H$ gene to improve the insemination performance of the boars.

\section{Vztah polymorfismu genu $G H$ a parametrů semene kanců}

Byl analyzován vztah polymorfismu genu Růstového Hormonu a parametry semene kanců. Za účelem zkoumání/analýzy byla u 173 kanců z periferní krve izolována DNA. U stáda studovaných kanců byla frekvence výskytu alely $G H / M s p$ I následující: alela $G H^{\mathrm{A}}-0,79$ a alela $G H^{\mathrm{B}}-0,21$. Co se týče polymorfismu $G H / H a e I I$ byla př́slušná frekvence následují- 
cí: alela $G H^{\mathrm{A}}$ - 0,53 a alela $G H^{\mathrm{B}}$ - 0,47. Byl analyzován vztah mezi genotypy $G H$ a charakteristickými rysy semene. Studie ukázala, že kanci s genotypem $G H^{\mathrm{B}} G H^{\mathrm{B}}$ obou polymorfních lokusů genu $G H$ produkovali ejakuláty o větším objemu, s vyšším procentem normozoospermie i s vyšším počtem následných inseminací ve srovnání s kanci $G H^{\mathrm{A}} G H^{\mathrm{A}}$ a $G H^{\mathrm{A}} G H^{\mathrm{B}}$. Naše současné výsledky naznačují, že polymorfismus u $G H / M s p \mathrm{I}$ a $G H / H a e I I$ může mít potenciální vliv na reprodukční výkonnost kanců.

\section{References}

BREIER BH, VICKERS MH, GRAVANCE CG, CASEY PJ 1998: Therapy with growth hormone: major prospects for the treatment of male subfertility? Endocrinology J 45: 553-560

FRANKS S 1998: Growth hormone and ovarian function. Baill Clin Endocrinol Met 12: 331-340

GELDERMANN H, MULLER E, BEECKMANN P, KNORR C, YUE G, MOSER G 1996: Mapping of quantitative trait loci by means of marker genes in $\mathrm{F}_{2}$ generations of wild boar, Pietrain and Meishan pigs. J Anim Breed Genet 113: 381-387

GRAVANCE CG, BRIER BH, VICKERS MH, CASEY PJ 1997: Impaired sperm characteristics in post pubertal growth hormone deficient dwarf rats. Anim Reprod Sci 49: 71-76

HANDLER J, SCHMOLL F, STUR J, BREM G, SCHELLANDER K 1995: Distribution of ApaI and CfoI polymorphisms of the porcine growth-hormone $(\mathrm{p} G H)$ gene in two RYR1 genotyped Austrian pig breeds. J Anim Breed Genet 113: 57-61

HULL RL, HARVEY S 2000: Growth hormone: a reproductive endocrine-paracrine regulator? J Reprod Fertil 5: $175-182$

IZADYAR F, ZHAO J, VAN TOL HT, COLENBRANDER B, BEVERS MM 1999: Synthesis of growth hormone in bovine ovary and cumulus oocyte complex during in vitro maturation. Theriogenology 51: 379

KARG H 1998: Manipulation of growth. Biotechnology for Livestock Production, FAO Plenum Press, New York pp.: 159-181

KIRKPATRICK BW, HUFF BM, CASAS-CARILLO E 1993: Double-strand DNA confirmation polymorphisms as a source of highly polymorphic genetic markers. Anim Genet 24: 155-161

KNORR C, MOSER G, MULLER E, GELDERMAN H 1997: Associations of $G H$ gene variants with performance traits in $\mathrm{F}_{2}$ generations of European wild boar, Pietrain and Meishan pigs. Anim Genet 28: 124-128

KONDRACKI S, GÓRSKI K, ARTOWICZ E 1998: Inseminacja swin w rejonie dzialania Stacji Unasieniania Loch w Lowiczu. PrzeglAd Hodowlany 5: 21-24

KUCIEL J, KRENKOVA L, URBAN T 1998: Polymorphisms of HaeII and MspI growth hormone genes in commercial hybrid pigs with different $R Y R 1$ genotypes. J Anim Breed Genet 115: 397-402

LARON Z, KLINGER B 1998: Effect of insulin-like growth factor I on serum androgens and testicular and penile size in males with Laron syndrome (primary growth hormone resistance). Eur J Endocrinol 138: 176-180

MACHNIK G, LECHNIAK D 2000: Funkcje hormonu wzrostu (GH) w meskich procesach rozrodczych. Med Wet 56: $218-221$

PUTNOVA L, KRENKOVA L, VRTKOVA I, DVORAK J, PIETRUSZKA A, CZARNECKI R 2001: Association of the DdeI growth hormone gene polymorphism with some performance traits in Polish Large White and Czech Large White x Polish Large White pigs. J Appl Genet 42: 317-324

REITER E, HUNNUY B, BRYNINX M, CORNET A, KLUG M, MCNAMARA M, CLOSSET J, HENNEN G 1999: Effects of pituitary hormones on the prostate. Prostate 38: 159-165

SCHELLANDER K, PELI J, KNEISSL F, SCHMOLL F, MAYR B 1994: Variation of the growth hormone gene in Ryr 1 genotyped Austrian pig breeds. J Anim Breed Genet 111: 162-166

SPITERI-GRECH J, NIESCHLAG E 1992: The role of growth hormone and insulin-like growth factor I in the regulation of male reproductive function. Horm Res 38: $22-27$

WIERZBOWSKI S 1996: Andrologia. PLATAN Kryspinów pp. 201-246

VIZE PD, WELLS JRE 1987: Isolation and characterization of the porcine growth hormone gene. Gene 55: 339-344

YERLE M, LAHBIB-MANSAIS Y, THOMSEN PD, GELLIN J 1993. Localization of the porcine growth hormone gene to chromosome $12 \mathrm{p1,2-p1,5}$. Anim Genet 24: 129-131

ZACHMANN M 1992: Interrelations between growth hormone and sex hormones - physiology and therapeutic consequences. Horm Res 38: 1-8 